\title{
Environmental impacts caused by residual vegetable oil in the soil-plant system
}

\author{
Sérgio Thode Filho ${ }^{1}$, Julieta Laudelina de Paiva ${ }^{2}$, Heider Alves Franco ${ }^{1}$, \\ Daniel Vidal Perez ${ }^{3}$ e Monica Regina da Costa Marques²
}

${ }^{1}$ Instituto Federal de Educação, Ciência e Tecnologia do Rio de Janeiro (IFRJ)

sergio.thode@ifrj.edu.br; heider.franco@ifrj.edu.br

${ }^{2}$ Universidade do Estado do Rio de Janeiro

paivaj@gmail.com;monicamarquesrj@gmail.com

${ }^{3}$ Embrapa Solos

daniel.perez@embrapa.br

\begin{abstract}
Vegetable oils are widely used for food production at different levels: domestic, commercial or industrial. The estimated production of vegetable oil, in Brazil, is three billion liters per year. Only 2.5\% of cooking oil waste (WCO) are recycled. The environmental impacts caused by WCO arrangement in soils still need to be better studied. The interaction of soils and organic pollutants makes it difficult to evaluate its behavior in the environment. This paper presents to evaluate the environmental impact of OVR in two Brazilian soils (sandy and loamy) and to estimate the terrestrial toxicity level (leakage test) and phytotoxicity (germination tests using lettuce seeds - Lactuca sativa L. - as well as in lettuce cultivation under greenhouse conditions). After leaching, the sandy soil had a slight lower WCO adsorption capacity than the clayey soil. The introduction of WCO caused clayey soil compaction. The WCO presence was toxic to earthworms, regardless of soil type. WCO negatively influenced germination and radicle growth in the eco toxicity assays. The different tested doses of WCO in lettuce (Lactuca sativa L.) cultivation caused changes in plant morphology for all physical parameters analyzed for both soils. We concluded that the WCO is a potential contaminant residue when improperly disposed over the soil, compromising the soil-plant system.
\end{abstract}

Keywords: Cooking oil waste. Contamination. Ecotoxicity. 


\section{Introduction}

Vegetable oils are widely used for food production at different levels: domestic, commercial or industrial. The estimated production of vegetable oil, in Brazil, is three billion liters per year. Only 2.5\% of cooking oil waste (WCO) are recycled. The remaining is improperly discharge in the sewage system, becoming potentially polluting for water resources and can cause many problems to wastewater treatment plants operation, provoking efficiency loss and increasing operational costs. (RABELO and FERREIRA, 2008; SABESP, 2011; ABIOVE, 2016).

In Brazil, waste management, such as WCO should follow the solid waste national policy - PNRS (Brazil, 2010), which does not allow its discharge into sewage pipe. However, there is no consensus about the appropriate environmental way for its disposal. The most accepted guidance is to put the oil in an enclosed container, such as a plastic bottle, and discard it in the municipal solid waste service to be landfilled. The disadvantage of this procedure is the possibility of a container leakage and a consequent environmental contamination (RABELO and FERREIRA, 2008).

Another possible source for environmental contamination with this type of waste can be its use as a chemical products emulsifier to spray over crops. The addition of small amounts of vegetable oils as an emulsifying agent in the spraying liquor of some crops favors the spread and absorption of herbicides (MENDONÇA et al., 2007). And, more recently, its use for soils contaminated with petroleum remediation. GONG et al. (2005a and 2005b) show that in contaminated sandy soils, the addition of vegetable oil facilitates the degradation of more than $90 \%$ of petroleum hydrocarbons.

The environmental impacts caused by WCO arrangement in soils still need to be better studied. The interaction of soils and organic pollutants makes it difficult to evaluate its behavior in the environment (FRANZETTI et al., 2006; MENDONÇA et al., 2007). The soil properties that must interact more with the pollutants are texture, permeability and organic matter content. The texture is the soil granulometric composition that indicates its proportion of sand, silt and clay. Clay soils have more retention sites and, consequently, organic pollutants tend to be more adsorbed; while sandy soils offer few binding sites and therefore have low adsorption. Permeability is controlled by the amount of void spaces in the soil that will allow water, and other liquids, to move along the soil profile and is dependent on how the particles that make up the soil organize themselves, creating porous spaces (BRADY and WEIL, 1999).

Tamada et al (2012) studied the bioremediation of sandy soils contaminated with vegetable oil (virgin and used) and with biodiesel. Toxicological tests (germination with lettuce seeds and avoidance test using earthworms) performed with contaminated soil samples at different treatment periods: $\mathrm{t}=$ zero, 60, 120 and 180 days. Soils contaminated with biodiesel presented 50\% germination inhibition at time zero and in other treatment periods. For the remaining oils, the germination inhibition increased over time, for virgin and residual vegetable oil (20\% to $12 \%)$ in 60 days, $(32 \%$ to $13 \%)$ in 120 days, $(40 \%$ to $65 \%)$ in 180 days, respectively. The germination inhibition caused by vegetable oils was attributed to the formation of toxic secondary compounds. On the other hand, in the tests with terrestrial organisms was not observed earthworm death. However, they showed weight gain in soils contaminated with vegetable oils, demonstrating that the vegetable oil and its degradation products were not toxic to them.

Although there are studies evaluating the environmental impacts of vegetable oils in soils. However, in the best of our knowledge, there is no comparison for WCO behavior in tropical soils with different textures. Hence, the objective of this study was to evaluate the environmental impact of OVR in two Brazilian soils (sandy and loamy) and 
to estimate the terrestrial toxicity level (leakage test) and phytotoxicity (germination tests using lettuce seeds - Lactuca sativa L. - as well as in lettuce cultivation under greenhouse conditions).

\section{Material and methods}

\subsection{Materials}

Were used two samples of tropical soils with different textures, collected between 0 and $20 \mathrm{~cm}$ depth (Table 1). The loamy - collected in Resende, RJ; and the sandy - collected in Seropédica, RJ. The sandy soil presented a bases saturation $\left(\mathrm{S}=\mathrm{Ca}^{2+}+\mathrm{Mg}^{2+}+\mathrm{K}^{+}+\mathrm{Na}^{+}=8.8\right)$ much superior to the one found in the loamy soil $(\mathrm{S}=3.7)$, as well as a high content of organic matter $(\mathrm{C}$. org. $=17.9)$, which is 3.7 times higher than in the loamy soil. In relation to bases saturation percentage, the sandy soil presented an excellent fertility condition and does not contain aluminum toxicity.

Table 1: Physical-chemical characterization of soils

\begin{tabular}{cccccccccccc}
\hline $\begin{array}{c}\text { Soil } \\
\text { Texture }\end{array}$ & $\begin{array}{c}\mathbf{p H} \\
\mathbf{H}_{\mathbf{2}} \mathbf{O}\end{array}$ & $\mathbf{C a}^{2+}$ & $\mathbf{M g}^{2+}$ & $\mathbf{K}^{+}$ & $\mathbf{N a}^{+}$ & $\mathbf{A l}^{3+}$ & $\mathbf{H}^{+}+\mathbf{A l}^{\mathbf{3 +}}$ & $\begin{array}{c}\mathbf{P} \\
\left(\mathbf{m g ~ d m} \mathbf{~ d m}^{\mathbf{3}}\right)\end{array}$ & $\mathbf{V}$ & $\mathbf{C . o r g}$ & $\mathbf{N}$ \\
\hline Sandy & 7.4 & 5.0 & 2.2 & 1.3 & 0.3 & 0.0 & 0.0 & 0.4 & 100 & 17.9 & 1.8 \\
Loamy & 5.3 & 2.9 & 0.5 & 0.1 & 0.2 & 0.3 & 3.0 & 3.0 & 53 & 4.8 & 0.5 \\
\hline
\end{tabular}

$\mathrm{V} \%=(\mathrm{Sx} 100) / \mathrm{S}+\mathrm{Al}^{3+}+\mathrm{H}^{+}$

To perform the tests were used lettuce seeds (Lactuca sativa L.) and earthworms (Eisenia fetida). The seeds were from ISLA PAK ${ }^{\circledR}$ with $99.7 \%$ purity, $81 \%$ germination and validity until July / 17, directly, without any previous procedure. The earthworms were acquired in adult stage with developed clitelo and average weight greater or equal to $300 \mathrm{mg}$.

Samples of residual vegetable oil (WCO) used, was collected from a voluntary delivery point. In this post, the residents deliver the used vegetable oil in a 2 L PET bottle. At the time of collection, the WCO was filtered in a cotton cloth to remove the larger particles and then packed in a $20 \mathrm{~L}$ recipient for smaller particles to decantation. The WCO used in this study was the supernatant after 30 days in the decantation tank.

\subsection{Methods}

\subsubsection{Dynamic percolation of waste vegetable oil in soil}

In the column experiment, four glass columns with $5.6 \mathrm{~cm}$ internal diameter and $16 \mathrm{~cm}$ height, packed with $250 \mathrm{~g}$ of each soil for 7 days, two columns for each kind of soil. After this period, $20 \mathrm{~mL}$ of WCO were added at $25 \mathrm{~min}$ intervals until drips into a collection vial, stopping the addition of WCO. After finishing the WCO percolation, the leaching process was initiated adding distilled water in $200 \mathrm{~mL}$ cycles, which were repeated as soon as the leaching stopped. After this period, the volumes of WCO added, the amount of water used in the leaching and the amount of WCO entrained in the leaching process were evaluated. 


\subsubsection{Seed germination}

Toxicity tests about radicle germination and development using lettuce seeds (Lactuca sativa L.) were performed to evaluate both, the lethal inhibition effects on seed germination and the sub lethal effects on radicle development (Sobrero and Ronco, 2004 and OECD, 2003). The experimental design had 6 treatments for the test group and one control group. The control group was composed of $4 \mathrm{~mL}$ of deionized H2O. The treatments for the test group were: A (0.1 mL OVR + $3.99 \mathrm{~mL}$ deionized H $2 \mathrm{O}), \mathrm{B}(0.5 \mathrm{~mL} \mathrm{OVR}+3.5 \mathrm{~mL}$ deionized H $2 \mathrm{O}), \mathrm{C}(1 \mathrm{~mL} \mathrm{OVR}+3$ $\mathrm{mL}$ deionized H $2 \mathrm{O}$ ) and D $3 \mathrm{ML} \mathrm{OVR}+1 \mathrm{~mL}$ deionized H $2 \mathrm{O}$ ). For all treatments, had three replicates. Twenty seeds of lettuce were placed in a Petri dish of $9.5 \mathrm{~cm}$ in diameter and moistened with the solution prepared according to established treatments, having as substrate a qualitative filter paper (porosity $14 \mu \mathrm{m}$ ). The Petri dishes were conditioned in a BOD incubator with photoperiod (CIENLAB and model CE-300/350-F) at a temperature of $25 \pm 2^{\circ} \mathrm{C}$ for $16 \mathrm{~h}$ light $/ 8 \mathrm{~h}$ dark. At the end of $120 \mathrm{~h}$, were evaluated the number of seeds germinated and the length of rootlets.

\subsubsection{Earthworm escape test}

The avoidance test (ABNT NBR 17512-1, 2011) were performed for both types of soil using transparent plastic boxes $(28.8 \mathrm{~cm} \times 10.8 \mathrm{~cm} \times 4.2 \mathrm{~cm})$. Ten adult earthworms (Eisenia fetida $\mathrm{sp}$ ) for each box exposed at the same time to a control soil and to a soil containing the test substances. Test and control soil were placed into each test box as well as the earthworms and presented to them a choice between the test soil and the control soil. After 48 hours, was evaluated the percentage of earthworms present in each soil.

Initially, using powers of $10\left(\mathrm{p}^{\mathrm{n}}\right)$ to determine the range of toxicity to investigate $1 \mathrm{~mL}, 10 \mathrm{~mL}$ and $100 \mathrm{~mL}$. After that, intermediate concentrations of WCO were used to determine the nearest toxicity range. For the sandy soil, the toxicity range was between 10 and $20 \mathrm{~mL}$, so the experiments were repeated with the dosages: $15 \mathrm{~mL}, 17 \mathrm{~mL}, 19$ $\mathrm{mL}$. For the clay soil the intermediate dosages were between 20 and $30 \mathrm{~mL}$, so the dosages evaluated were $24 \mathrm{~mL}, 25$ $\mathrm{mL}, 26 \mathrm{~mL}$. Each experiment performed in triplicate for each soil.

The tests response for the two soil types containing WCO was calculated in terms of avoidance percentage per concentration. The avoidance percentage was calculated based on the following formula: $A=[(C-T) / N] \times 100$, where $\mathrm{C}$ is the number of animals found in the control soil, $\mathrm{T}$ and the number of animals found on the test soil, and $\mathrm{N}$ the total number of animals used per treatment (for each concentration tested). A positive and indicative avoidance result is a negative attraction by the concentration of the active ingredient tested. According to the norm, $0 \%$ of escape indicates animal attraction to the chemical substance evaluated. On the other hand, a soil is considered toxic when more than $80 \%$ of exposed organisms prefer the control soil (leakage> 60\%) (ABNT, 2011).

\subsubsection{Plantation in pots}

The lettuce planting was conducted in a greenhouse, located in the central region of Rio de Janeiro, latitude 22 $\circ 54$ '36.9 "S and longitude $43^{\circ} 14^{\prime} 09.6$ " W in 01/01/2016 to 12/02/2016 period (30 days). The lettuce seedlings were produced in a rectangular tray $(54.5 \mathrm{~cm}$ x $28.7 \mathrm{~cm}$ ) divided into 128 smooth and streak less cells (diameter superior 3.7 $\mathrm{cm}$ and diameter inferior $1.1 \mathrm{~cm}$ with $5 \mathrm{~cm}$ depth). In each cell, 2 seeds were settled. After growth, the seedlings with approximately $4 \mathrm{~cm}$ height and 3 leaves were transplanted to plastic vases $(10 \mathrm{~cm} \mathrm{x} 10 \mathrm{~cm} \times 15 \mathrm{~cm}) \mathrm{containing} 1.5 \mathrm{~kg}$ of soil per pot. 
A randomized complete block design with four treatments and three replicates $(4 \times 3)$ was performed. The WCO dosages for each soil texture were defined considering the earthworms avoidance test (item 2.2.2.2). For the sandy soil, the dosages were $20 \mathrm{~mL}, 30 \mathrm{~mL}$ and $40 \mathrm{~mL}$. For the loamy soil were: $26 \mathrm{~mL}, 36 \mathrm{~mL}, 46 \mathrm{~mL}$. The control group was carried out in the soil without addition of WCO. Twice a day the pots were irrigated to maintain soil moisture near the field capacity. The soil nutrients deficiency correction of was made with commercial formulated fertilizer 4-14-8, using $1 \mathrm{~g}$ for the clay soil and $0.6 \mathrm{~g}$ for the sandy soil per pot. After 30 days, the plants were harvested and root length (RL) and aerial parts measured. Height $(\mathrm{H})$, crown diameter (CD), neck diameter (ND), total number (TN) of leaves greater than $10 \mathrm{~cm}$ (TLM), largest and width leaf length (WML), width of the largest leaf (LMF).

\subsubsection{Statistical analysis}

The germination tests measurements and the planting experiments physical evaluations were analyzed using a graduated ruler and a digital caliper. After these measurements, the parameters averages were calculated and Tukey's test used to evaluate the significance at 0.05 (5\% probability) among them (COSTA NETO, 1977; MILLER; MILLER, 1993).

To determine the existence of a possible correlation between the pollutant dosage and the toxicity tests was used Pearson's correlation coefficient (r) (ACHEN, 1977; ALDRICH, 1995).

All calculations and graphs presented in this work were performed by BioEstat 5.0 and SigmaPlot 12.5 software.

\section{Results and discussion}

\subsection{Dynamic percolation of waste vegetable oil in soil}

WCO average dosage required to saturate the loamy soil was $118 \mathrm{~mL} / 250 \mathrm{~g}$, while the sandy soil needed 88 $\mathrm{mL} / 250 \mathrm{~g}$. The higher WCO adsorption capacity was in the loamy soil, approximately $35 \%$ higher when compared to the sandy one.

After the column saturation procedure, the leaching step started at adding $200 \mathrm{~mL}$ portions of distilled water. For the sandy soil, 8 portions, that is, $1600 \mathrm{~mL}$ were sufficient to not observe the WCO percolation. Then, the water addition was interrupted. The WCO total volume percolated was $10.11 \mathrm{~mL}$. On the other hand, in the loamy soil, the presence of WCO turned this soil impermeable, preventing second portion of water percolation, that is, only $200 \mathrm{~mL}$ of water were added. However, even with little percolated water, WCO volume percolated was $32.5 \mathrm{~mL}$. After leaching, the sand soil showed a slight lower WCO adsorption capacity $(77.89 \mathrm{~mL})$ than the loamy soil $(85,5 \mathrm{~mL})$. The WCO adsorption in the sandy soil was higher than expected (only $10 \%$ lower than the clayey soil) due to its high content of organic matter $(17.9 \%)$ or presence of lower contents of clay $2: 1$. In the case of loamy soil, the WCO adsorption is mainly due to the active sites of the clays (LIBARDI, 2005). The clay particles are more chemically active than the sand particles because of their nanometric dimensions, making them present colloidal properties. The most important property is the affinity for water and chemical elements dissolved therein. This affinity is mainly due to existence of electric charges on the clay surface (LEPSCH, 2002).

WCO in the loamy soil causing its impermeability is possibly due to soil compaction provoked by clay particles translocation. This movement occurs when water and/or another liquid substance percolate through a dry soil, 
suspending part of the clay particles, and transport them along the soil profile. An adsorption of water and / or liquid substances by the soil mass will cause deposition of the suspended clay particles, filling the empty porous spaces, forming compacted layers in the soil (SWAN; MONCRIEF; VOOHEES, 1987).

\subsection{Seed germination}

Were performed acute phytotoxicity tests by germination and root development to evaluate, both lethal effects through seeds non-germination and sublethal effects in root development caused by direct contact with the OVR. Figure 1A shows the germinated seeds percentage for the control group (distilled water) was $95 \%$ and for the treatment using OVR groups was below $88 \%$. From $1 \mathrm{~mL}$ the germination percentage was below $80 \%$ (1 mL with $79 \%$ and $3 \mathrm{~mL}$ with $63 \%$ ). The p-value was 0,0003 and it indicates that there was statistical difference between control group and treatments.

According to Beweley and Black (1994), the germinated seeds percentage is regulated by internal seeds balance factors and external environmental factors, such as, light, humidity, temperature and oxygen concentration. Moreover, oily substances tend to wrap the seeds with a film, thus forming a physical barrier, preventing water and oxygen transfer, as well as stopping nutrients absorption and gas exchanges (VAUHKONEN et al., 2008; VWIOKO and FASHEMI, 2005 and NJOKU et al., 2009a, 2009b). In this study, dosages above $1 \mathrm{~mL}$ should have been enough to wrap the seeds, making difficult to exchange gas.
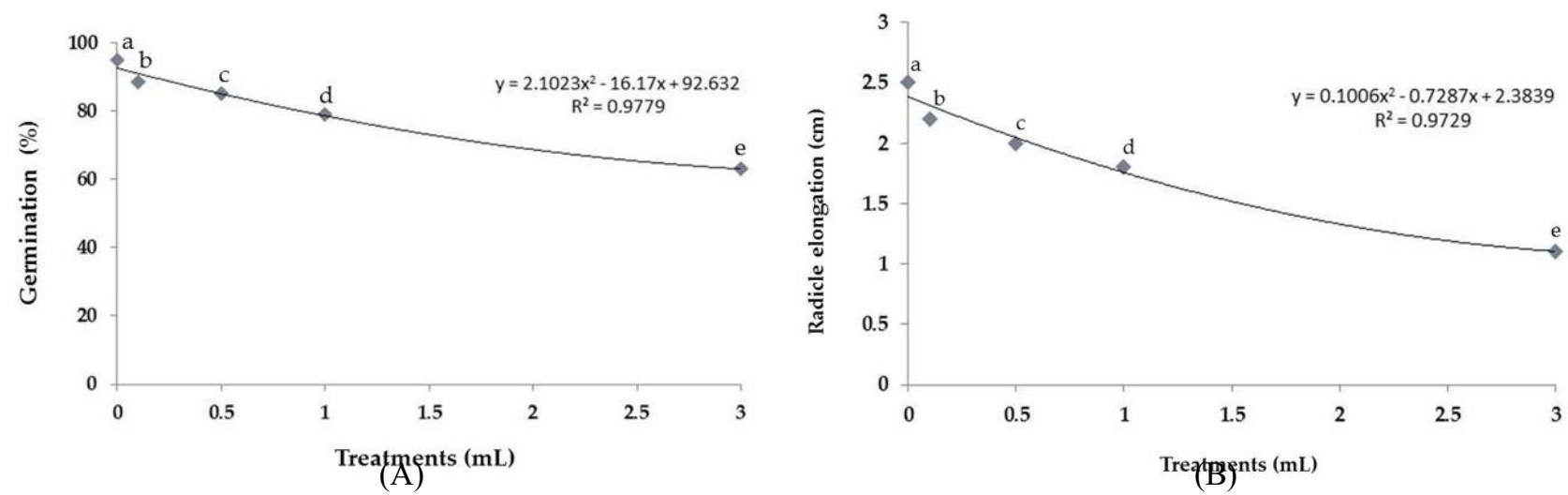

Figure 1 - Germination tests of lettuce seeds (Lactuca sativa L.) (A) Percentage of germination; (B) Root length: with different dosages of WCO - (a) Control; (b) 0,1 mL WCO; (c) 0,5 mL WCO; (d) $1 \mathrm{~mL} \mathrm{WCO,} \mathrm{(e)} 3 \mathrm{~mL}$ WCO. Means followed by the same lowercase letter do not differ statistically from each other by Tukey test $\mathrm{p} \leq 0.05$ probability. (A) germination $(\%)$; $(\mathrm{B})$ radicle elongation $(\mathrm{cm})$.

The control group had a $2.5 \mathrm{~cm}$ radicle length. As WCO dosage was increased, the radicle growth inhibition increases (Figure 1b). At $0.1 \mathrm{~mL}$ dosage, the inhibition was 12\% lower compared to the control group, whereas the 3 $\mathrm{mL}$ dosage inhibition reached $56 \%$. There was a highly significant negative match of -0.953 . That is, $95 \%$ root growth inhibition is associated with $\mathrm{WCO}$ and $5 \%$ to other factors.

Was observed that the radicle growth was more sensitive to WCO than the germination. The evaluation of WCO effect on root elongation may reflect compounds toxicity even at very low concentrations (SOBRERO e RONCO, 2004; TAMADA et al., 2012), which are not sufficient to inhibit germination but may delay or inhibit the root elongation process depending on this compounds mode and site of action. In this study, the very low solubility of WCO in water showed to be sufficient to cause root elongation inhibition. 


\subsection{Earthworm avoidance test}

In sandy soil, the rapid earthworm avoidance response in WCO dosages less than $20 \mathrm{~mL} / 250 \mathrm{~g}$ sandy soil did not provoke the avoidance by more than $60 \%$ (Figure $2 \mathrm{a}$ ), indicating that above this dosage, soil became toxic to earthworms. In the case of loamy soil, the earthworms tolerance was slightly higher. Dosages less than $26 \mathrm{~mL} / 250 \mathrm{~g}$ sandy soil did not provoke the avoidance by more than $60 \%$ (Figure $2 \mathrm{~b}$ ). A quadratic relation was observed between the WCO dosage and the avoidance.

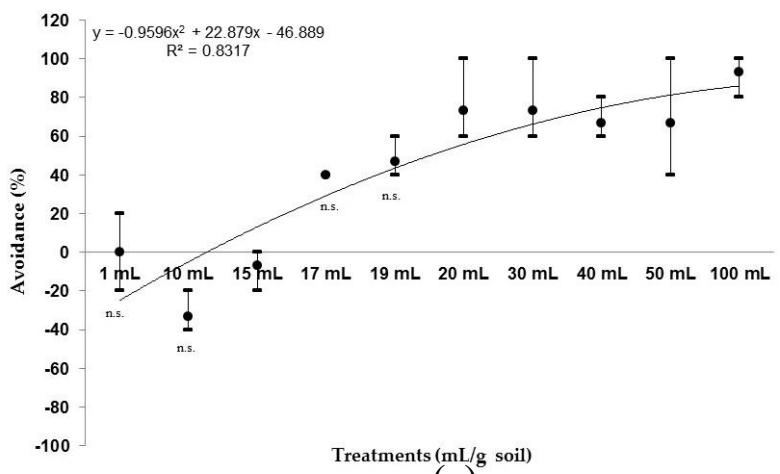

(a)

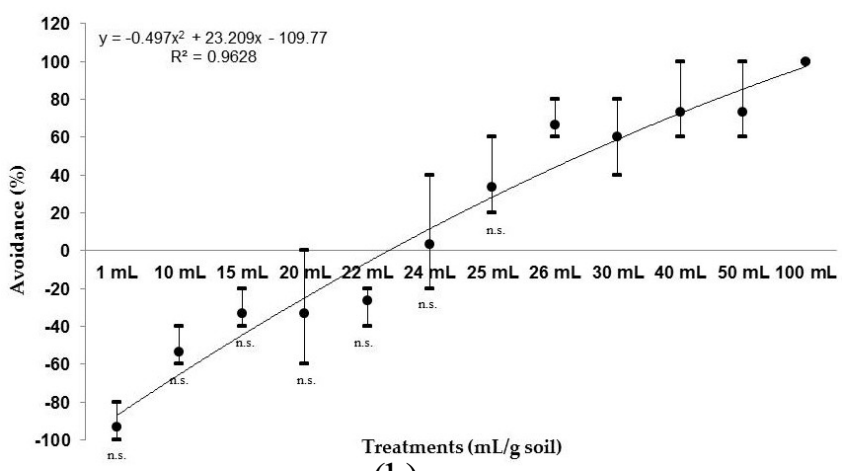

(b)

Figure 2 - Figure 2(a) and figure 2(b). Eisenia fetida avoidance response contaminated with different vegetable oil waste dosages. Mean values and standard deviation bars, Tukey test, $\mathrm{p} \leq 0.05$; n.s. = not significant. (a) sandy soil; (b) loamy soil.

Wang et al. (2010) studied the rapid escape response of the earthworm with petroleum sludge and found that the limiting dose was $0.17 \mathrm{~g} \mathrm{~g}^{-1}$ soil. The WCO is 4.33 times less impacting to earthworms than crude oil, although that also produced an improper habitat for earthworm.

\subsection{Plantation in pots}

The results of WCO dosing effect on lettuce cultivation in sandy soil are in Figure 3. In all evaluated parameters, WCO produced a remarkable inhibition in plant growth compared to control group. The height (H), as well as the crown diameter (CD), the neck diameter (ND), the total leaves per plant (TLP), the length of the largest leaf (LLL) and the width of the largest leaf (WLL) showed a 45\% inhibition in relation to control group. For all tested doses the length of all leaves (LAL) was less than $10 \mathrm{~cm}$. Root length (RL) was the parameter less influenced by the pollutant.

The WCO influence on lettuce cultivation on loamy soil is presented in Figure 3. In all parameters studied, there was no significant difference between WCO dosages. H, DCP, DC, TFP, CMF, LMF and CR showed $25 \%$ inhibition compared to the control group. The total number of leaves above $10 \mathrm{~cm}$ (TFM) was the parameter that was most influenced by the WCO dosage. On the other hand, larger leaf width (LLW) was the one that suffered less influence in comparison with the other parameters. 


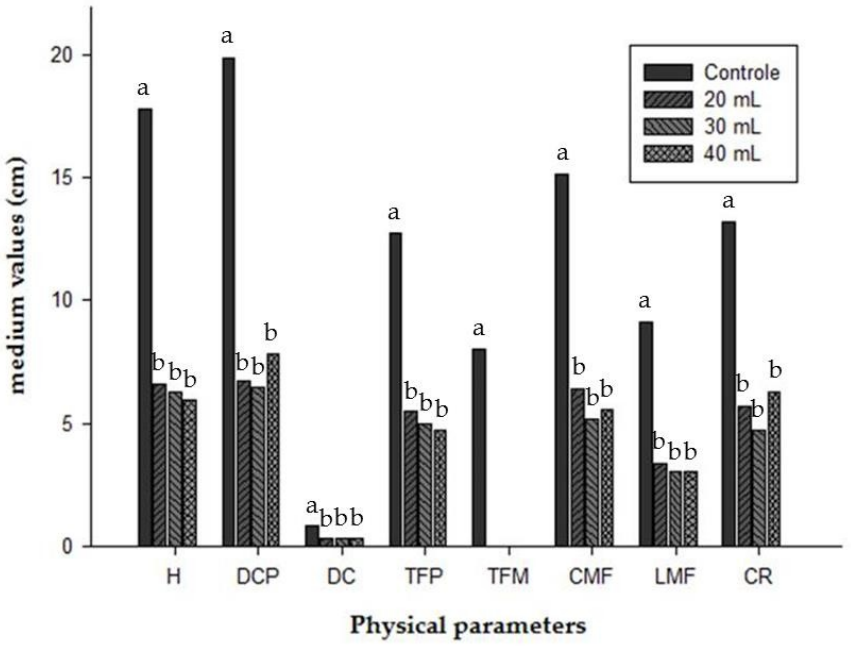

(a)

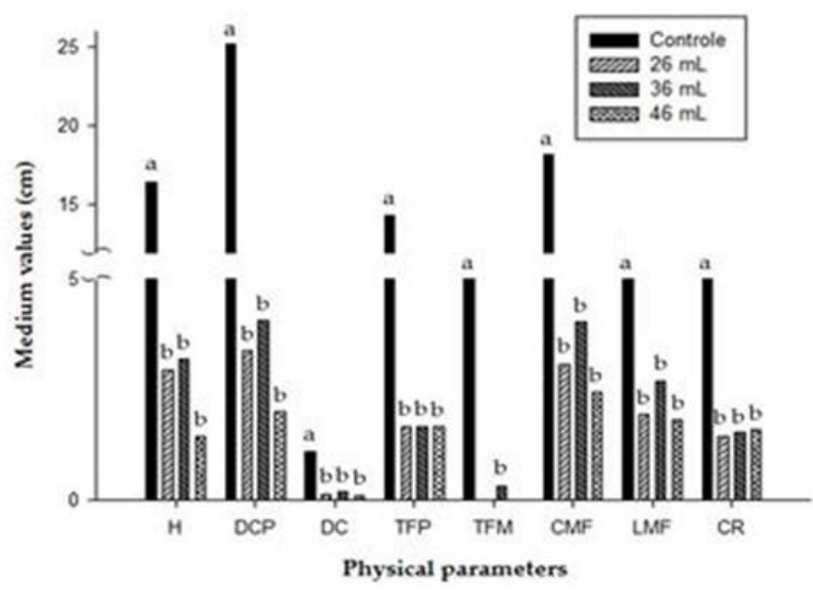

(b)

Figure 3 - Evaluation of the physical variables for lettuce cultivation in different soils, contaminated with different dosages of residual vegetable oil: (H) height; (DCP) Cup diameter; (DC) Diameter of the neck; (TFP) Total leaves per plant; (TFM) Total leaves greater than $10 \mathrm{~cm}$; (CMF) Length of largest leaf; (LMF) Larger sheet width. Means followed by the same lowercase letter do not differ statistically from each other by Tukey test $\mathrm{p} \leq 0.05$ probability. (a) sandy soil; (b) loamy soil.

Figure 4 presents the Pearson Correlation Coefficient (r) that measure the linear relationship between WCO dosage and plant growth in both types of soil.

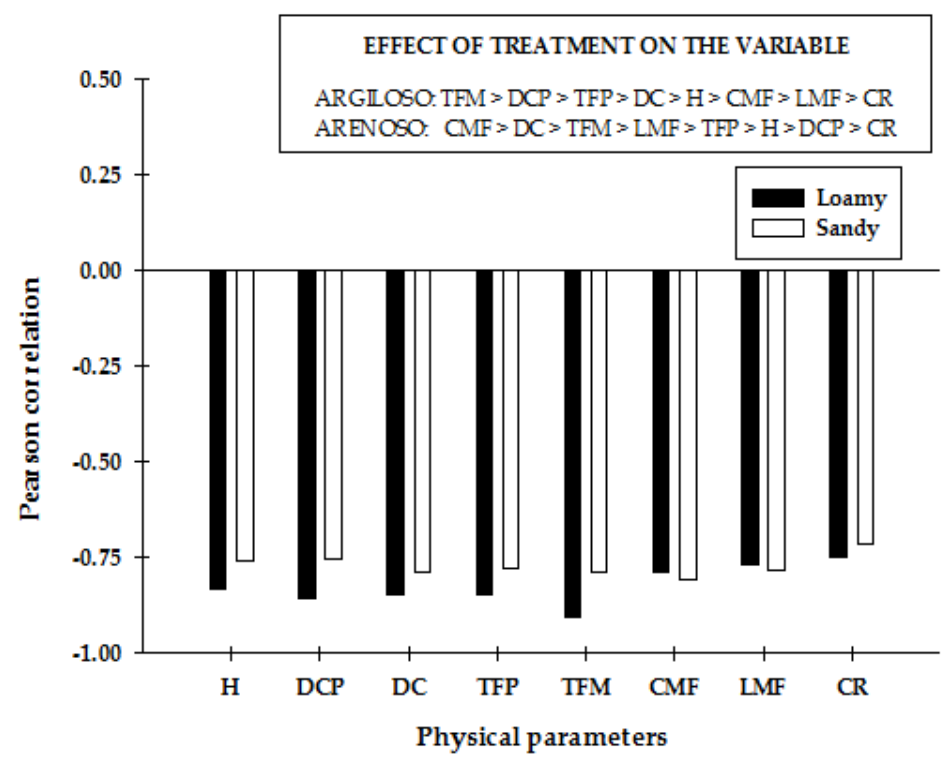

Figure 4. Pearson correlation coefficient response between WCO dosage and plant growth in both types of soil. Coefficient Interval (r) interval: $[-1,1]$.

For sandy soil, the Pearson correlation coefficient (r) found for most physical parameters was slightly lower than that found for loamy soil. However, in all parameters, the influence of the dosage was strongly negative. Plant growth was inverse proportional to the amount of WCO added to the soil. The length of the largest leaf (LLL) was the physical parameter that presented the highest correlation for both soils: loamy (-0.9058) and sandy (-0.7873). 
There is a direct relationship between root and the other plants parts. The roots are important for water and nutrients absorption from the soil, which move them to the aerial growth points (REIS, 2006). The plants ability to obtain water and mineral nutrients from the soil is related to their extensive root system (TAIZ et al., 2017). However, soil compaction and water availability may reduce or even impede the roots development (SOUZA et al., 2006, BENGOUG et al., 2006). The water content reduction in the soil increases the cohesion between the particles and decreases the hydrostatic cells pressure in the roots, restricting the plant root growth (HAMZA \& ANDERSON, 2005, REIS et al., 2006).

\section{Conclusion}

After leaching, the sandy soil had a slight lower WCO adsorption capacity than the clayey soil. The introduction of WCO caused clayey soil compaction. The WCO presence was toxic to earthworms, regardless of soil type. WCO negatively influenced germination and radicle growth in the eco toxicity assays. The different tested doses of WCO in lettuce (Lactuca sativa L.) cultivation caused changes in plant morphology for all physical parameters analyzed for both soils. In conclusion, WCO is a potential contaminant residue when improperly disposed over the soil, compromising the soil-plant system.

\section{References}

ABIOVE. Associação Brasileira das Indústrias de Óleos Vegetais. 2012. [cited 2016 jan 18]. Available from: <http:// www.abiove.com.br/menu_br.html>.

ASSOCIAÇÃO BRASILEIRA DE NORMAS TÉCNICAS. NBR ISO 17512-1. Qualidade do solo - Ensaio de fuga para avaliar a qualidade de solos e efeitos de substâncias químicas no comportamento. Parte 1: Ensaio com minhocas (Eisenia fetida e Eisenia andrei). Rio de Janeiro: 2011.

ACHEN, Christopher H. Measuring Representation: Perils of the Correlation Coefficient. American Journal of Political Science. 1977; 21 (4): 805-815.

ALDRICH, John H. Correlations Genuine and Spurious in Pearson and Yule. Statistical Science. 1995; 10 (4): $364-$ 376.

BENGOUGH, A.G.; BRANSBY, M.F.; HANS, J.; MCKENNA, S.J.; ROBERTS, T.J. \& VALENTINE, T.A. Root responses to soil physical conditions: growth dynamics from field to cell. J. Exp. Bot. 2006; 57:437-477.

BEWLEY, J.D.; BLACK, M. Seeds: physiology of development and germination. New York, Plenum Press, 2ed, 1994. 445p.

BRADY, Nyle C.; WEIL, Ray R. Elementos da natureza e propriedades dos solos. Bookman Editora, 2013.

BRASIL. Presidência da República. Lei no 12.305, de 2 de agosto de 2010. Institui a Política Nacional de Resíduos Sólidos; altera a Lei no 9.605, de 12 de fevereiro de 1998; e dá outras providências. Diário Oficial da [União]. Brasília, DF, 3 agosto 2010.

COSTA NETO, P. L. O. Estatística. São Paulo: Edgard Blücher, 1977. 264p.

FRANZETTI, A.; Di GENNARO, P.; BEVILACQUA, A.; PAPACCHINI, M.; BESTETTI, G. Environmental features of two commercial surfactants widely used in soil remediation. Chemosphere. 2006; 62: 1474-1480. 
GONG, Z. et al. Dissolution and removal of PAHs from a contaminated soil using sunflower oil. Chemosphere. 2005a; 58(3): 291-298.

GONG, Z. et al. Influence of soil moisture on sunflower oil extraction of polycyclic aromatic hydrocarbons from a manufactured gas plant soil. Science of the total environment. 2005b; 343 (1): 51-59.

HAMZA, M.A. \& ANDERSON, W.K. Soil compaction incropping systems: A review of the nature, causes and possible solutions. Soil Till. Res. 2005; 82:121-145.

LEPSCH, IGOR. Formação e conservação de solos. São Paulo. Oficina de Textos, 2002.

MENDONÇA, C.G. DE; RAETANO, C.G.; MENDONÇA, C.G. DE. Tensão superficial estática de soluções aquosas com óleos minerais e vegetais utilizados na agricultura. Engenharia Agrícola, Jaboticabal. 2007; 27: 16-23.

MILLER, J.C. \& MILLER, J.N. Statistics for analytical chemistry. 3a ed. Chichester: Ellis Horwood. $233 p ., 1993$.

MILLIOLI, V. S.; Servulo, E.F.C. ; SOBRAL, L. ; Carvalho, D. Dias . Biorremediation of crude oil-bearing soil: Evaluating the effect of rhamnolipid addition to soil toxicity and crude oil biodegradtion efficiency. Global NEST Journal. 2009; 11: 181-1889.

NJOKU, K.L.; AKINOLA, M.O.; TAIWO, B.G.. Effect of gasoline diesel fuel mixture on the germination and the growth of Vigna unguiculata (Cowpea). African Journal of Environmental Science and Technology. 2009; 3 (12).

(OECD) Organisation for Economic Co-operation and Development. OECD Guideline for the testing of chemicals. Proposal for updating guideline 208. Terrestrial Plant Test: 208: Seedling Emergence and Seedling Growth Test; 2003.

RABELO, R. A.; FERREIRA, O. M. Coleta seletiva de óleo residual de fritura para aproveitamento indústria. 2008. [cited 2016 abr 14]. Available from: <http://www.ucg.br>.

REIS, G. G. dos; REIS, M. das G. F.; FONTAN, I. da C. I.; MONTE, M. A.; GOMES, A. N.; OLIVEIRA, C. H. R. de; Crescimento de raízes e da parte aérea de clones de híbridos de Eucalyptus grandis X Eucalyptus urophylla e de Eucalyptus camaldulensis X Eucalyptus spp submetidos a dois regimes de irrigação no campo. R. Árvore, Viçosa-MG. 2006; 30 (6): 921-931.

SABESP. Reciclagem de óleo de cozinha, 2011. [cited 2016 abr 14]. Available from: <http://site.sabesp.com.br>.

SOBRERO, Maria Cecilia; RONCO, Alicia. Ensayo de toxicidad aguda con semillas de lechuga (Lactuca sativa L.). Ensayos toxicológicos y métodos de evaluación de calidad de aguas. IDRC/IMTA. Canadá. 2004; 4: 71-79.

SOUZA, E.D.; CARNEIRO, M.A.C.; PAULINO, H.B.; SILVA, C.A. \& BUZETTI, S. Frações do carbono orgânico, biomassa e atividade microbiana em um Latossolo Vermelho sob cerrado submetido a diferentes sistemas de manejos e usos do solo. Acta Sci. Agron. 2006; 28:323-329.

SWAN, J.B.; MONCRIEF, J.F.; VOOHEES, W.B. Soil compaction causes, effects, and control. St. Paul: University of Minnesota, 1987. Agriculture Bulletin, 3115.

TAIZ, L. et al. Fisiologia e desenvolvimento vegetal. 6. ed. Porto Alegre: Artmed, 2017.

TAMADA, I.S., Montagnolli, R.N., Lopes, P.R., Bidoia, E.D., 2012. Toxicological evaluation of vegetable oil sand biodiesel in soil during the biodegradation process. Braz. J. Microbiol. 43 (4), 1576-1581.

VAUHKONEN, V.; LAUHANEN, V.; SUOJARANTA, S. The phytotoxic effects and biodegradability of stored rapeseed oil and rapeseed oil methyl ester. Agric. Food Sci. 2008; 20 (2): 131-142.

VWIOKO, D.E.; FASHEMI, D.S. 2005. Growth response of Ricinus communis L (Castor Oil) in spent lubricating oil polluted soil. Journal of Applied Sciences and Environmental Management. 2005; 9 (2): 73-79.

WANG, Shi-Jie et al. Ecotoxicity assessment of aged petroleum sludge using a suite of effects-based end points in earthworm Eisenia fetida. Environmental monitoring and assessment. 2010; 169 (1-4): 417-428. 